\title{
METHODS OF MANUFACTURE AND INNOVATIONS IN STEEL AEROSOL CANS' PRODUCTION
}

\author{
Katarzyna Niemiec ${ }^{1,2}$, Anna Fitrzyk ${ }^{2}$, Cezary Grabowik ${ }^{1}$ \\ ${ }^{1}$ Silesian University of Technology, Faculty of Mechanical Engineering, Konarskiego 18A, \\ 44-100 Gliwice, Poland \\ 2 JagoPro Sp. z o.o., ul. Szczakowska 35, 43-600 Jaworzno, Poland \\ Corresponding author: Katarzyna Niemiec, katarzynaniemiec@jagopro.pl
}

\begin{abstract}
The production of aerosols has had a significant position in the industry for many years. We use aerosol products almost every day for very different purposes. The aerosol industry growth very dynamically, the shapes and the materials of the containers are changing, but the main principle remains the same - "aerosol dispenser shall mean any non-reusable container made of metal, glass or plastic and containing a gas compressed, liquefied or dissolved under pressure, with or without a liquid, paste or powder, and fitted with a release device allowing the contents to be ejected as solid or liquid particles in suspension in a gas, as a foam, paste or powder or in a liquid state" [3]. The purpose of this article is to present the methods of aerosols' steel can manufacture together with the changes that have been made over the last century. Since the beginning of aerosol industry metal is the main material from which aerosol containers are made of, and steel is one of the most popular raw materials, the main law requirements regarding aerosol containers made of steel will be analysed. As the consequence of these analyses, the future possible development directions will be shown.
\end{abstract}

Key words: aerosol containers, innovation, steel, aluminium.

\section{INTRODUCTION}

The first pressurized containers were invented and tested in XIX century and were used for carbonated beverages, local skin anaesthesia or perfumes and were made of metal and glass [2]. The history of the cans which we know starts when Erik Rotheim patented his first aerosol dispenser. The official dates differ in different sources as he submitted a patent for an aerosol dispenser to the Norwegian patent office in 1926 (granted in 1929), and in the United States in 1927 (approved in 1931) [21]. The first Rotheim's products were made of steel which was $2.3 \mathrm{~mm}$ thin, weighted 397 grams, could hold the pressure of 131 bars and were supposed to be refilled [16]. Although the first patent for an aerosol dispenser was given in Europe, the common usage of the pressurized containers took place in the United States during World War II when anti-insect agents were used in "bug bomb" aerosol products $[2,5,16]$. Right after the war they were released for sale for civilians and since that time aerosol products became developed in Europe and United States.

Nowadays, global production of aerosol products exceed yearly 15 billion. In 2019 the three biggest producers of the world are Europe $(5,49$ billion units), US (3,67 billion units) and China (2,57 billion units) [6]. Out of those numbers metal aerosol containers make up $99 \%$ of the market - aluminium is approximately $55 \%$ and steel is $44 \%$ [10].

\section{STEEL AEROSOL CONTAINERS}

The first widely used aerosol cans were made of steel. Invented in 1946-47 by Harry E. Peterson they were lighter, disposable and not so expensive. They looked differently from the present cans as their top section was carrying the small valve which was already assembled to the can by the can maker and they were filled upside-down. The closing of a container was made after the filling when the end was double-seamed to the body. A very big innovation was made in about 1951 when Crown Cork and seal Company developed a 1-inch hole with corresponding valve cup [14]. This feature was accepted by all aerosol container manufactures in US, and now it is widely used [11].

\subsection{Tinplate}

Tinplate is a mild-steel sheet which is covered with a very thin coating of tin on both sides. It is a corrosion resistance material, which protects the filling against external factors. Tin coating thickness can vary in different metal packaging industries.

Earlier the tinplate was produced by the hot dipping process where both sides were coated equally. Nowadays, the most common method is 
electrodeposition commercially introduced in 1937 where two sides of steel can be differently coated with tin. In 2009 about $80 \%$ of aerosols produced in the United States was made from electrolytically tinplated sheet (electro tinplate - ETP) and about 5\% electro chromic steel (ECCS) [15].

The modern tinplate production process consists of the below steps [24]:

a)Pickling - the first step which is done to remove the rust from the steel.

b)Cold rolling - the second step which is made to reduce the thickness of the coil. The coil passes through five-, six- and even seven stand mills [17]

c)Degreasing - next step where the oil and grease used in the mills for thickness reduction is washed here with the help of alkali.

d)Annealing - it is done to remove work-hardening effects and to obtain mechanical properties and optimal grain structure.

e)Temper rolling - is the process of light cold rolling which is made to strength the coil and to create specific surface structure

f)Tin coating - when the coil is properly prepared in previous steps, the coils are washed with the help of Sulphuric acid. Then they are coated with tin in the electrolysis process. After the coating, the tinplate is washed, dried and sprayed with oil in order not to stick.

g) Cutting - after the tinning process the coils are is cut into sheets or are coiled according to customers specifications. On the figures number 1 and 2 tinplate in coil and sheets are presented.

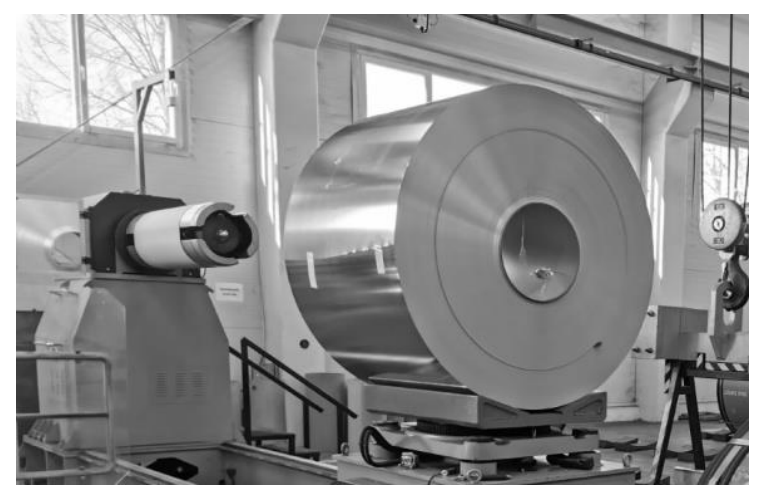

Fig. 1. Tinplate in coils (source: Pikopack)

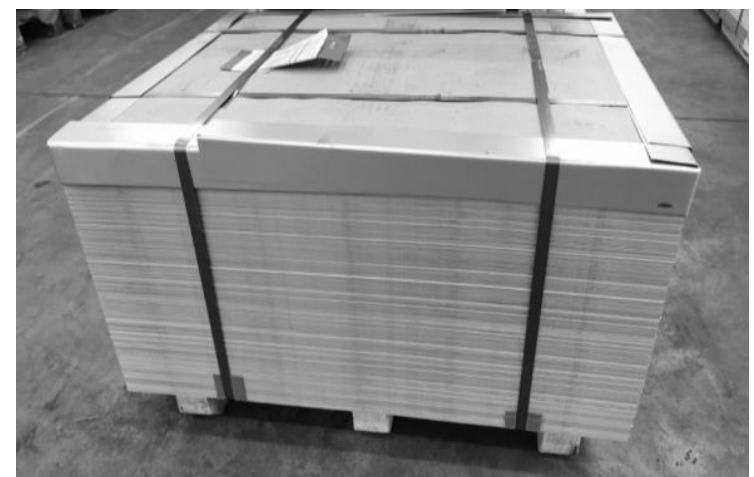

Fig. 2. Tinplate cut into sheets (source: Pikopack)

\subsection{Tinplate aerosol cans}

One-piece steel extrusion cans are very rare on the market, despite the fact that they have the highest mechanical strength compared to other types of aerosol cans, allowing the working pressure of the propellant to be 45 bar. Their use is limited mainly due to high manufacturing costs. Two-piece containers (embossed or pressed and drawn) are made from two main elements: a side with a bottom and a cover or a side with a lid and a bottom [8].

Presently, the most popular tinplate aerosol can is made from three pieces, as presented on Figure number 3:

1. Body

2. Top (Dome) - in UK also named cone

3. Bottom (Base) - in UK also named dome.

The differences in US and UK nomenclature sometimes lead to confusion [15].

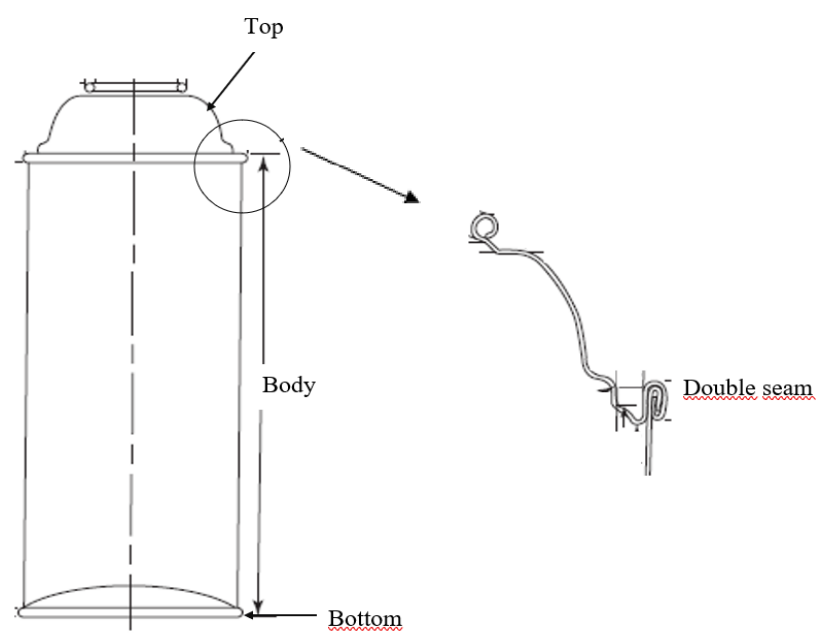

Fig. 3. Three-piece aerosol can [own drawing based on 14]

The three-pieces containers enable to obtain the working pressure of the propellant at the level of 12 to 18 bar. The most commonly used steel containers on the European market have a diameter of 45 to 65 $\mathrm{mm}$.

\subsection{Manufacturing process of tinplate cans}

The three-pieces tinplate cans production is divided into several steps and the whole process does not take place on one production line only. Tops and bottoms are manufactured separately from the body, varnishing and colouring operations also take place on separate production lines.

\subsubsection{Coil cutting process}

Depending on the can making factory possibilities, the tinplate is delivered in coils and is cut in the factory, or it is already delivered in sheets with dimensions depending on the can size.

During coil cutting process several quality controls are made: surface control, surface tension control with a special liquid (very important for the proper 
coverage during the lacquering), tin coating thickness control, hardness control as well as dimensional controls such as: tinplate thickness control (tinplate thickness of body and top and bottom ends of aerosol cans changes in accordance with pressure resistance requirement), width and length of tinplate sheets (determined according to aerosol can dimensions), burr control test (to prevent interruptions and scratches in the following process), perpendicularity test to determine deviation from $90^{\circ}$ (to prevent blockage and interruptions in the manufacturing machines and skewness on lacquering / printing) .

\subsubsection{Lacquering (varnish) process}

Steel covered with tin already have the higher resistance to corrosion than for example aluminium. This is why some types of formulas do not require additional lacquering [19]. But still about 50\% of the tinplate aerosol cans have organic linings. The internal part of the tinplate is covered once, twice or even three times when such a protection is required. The most common are epoxy phenolics, then vinyl organosols, polyamide-imide (PAM) and polyimideimide (PIM). Although PAM and PIM are costly and quite difficult to apply on the tinplate, they are very resistant to permeation [18]. The very thin layer of organic linings is applied to a flat plates and then are cured in continuous ovens. It is necessary to leave the surface of the tinplate which will be welded without any coating, so that the seam will be well-formed.

During lacquering process, in order to guarantee coating performance of the can, there are several tests made. First of them are internal and external coating thickness measurements performed by a coating thickness gauge. Then internal and external coating performance is controlled on coated tinplate by acetone and copper sulphate (CuSO4) solution. Another test is welding line control test which is carried out to check contamination on the welding line. Any kind of contamination on the welding line might affect welding operation and proper welding. Additionally, also the cross-cut test is made where the ability of coating resistance and the adhesion of dry coating of printing on printed sheets by means of a series of cuts through the coating is measured.

\subsubsection{Printing process}

Aerosol cans can be decorated during can production process or covered with labels. If the cans are printed in the can factory, the offset printing is used. This process uses a metal plate and rubber cylinder and then the ink is transferred to the flat tinplate. The basic offset printer is built from 2-4 printing units (using CMYK colours). But nowadays more expanded printers can be used with more printing units - up to 8, UV coating machine, UV dryers, and folding units at the end.
Decorating also must be controlled during the production process. Firstly, the print itself is compared with the print proof visually or using spectrophotometer. Moreover, resistance tests are made: scratch resistance test, solvent resistance test.

\subsubsection{Slitting (cutting) process}

During cutting process large rectangular sheets with lacquer and/or lithography are cut with circular knives on the tandem slitters. The shape of the plate corresponds to the required size of the can body, respectively with the allowance for welding and seaming [26].

After the slitting the perpendicularity test, which is presented on Figure 4, is made again in order to find out if there are any deviations from $90^{\circ}$ corners. This kind of deviations might cause the blockage and interruptions in the manufacturing machines and enable proper welding and seaming.

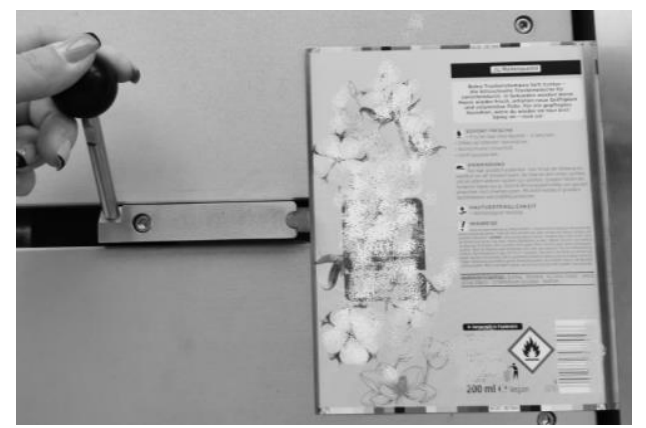

Fig. 4. Perpendicularity test (source: Pikopack)

\subsubsection{Welding process}

The slittered can bodies are properly loaded into feeding place, where from they are transferred through double blank detectors and then flexed into forming rolls where the rounding process take place. To join two edges of the rounded sheet the material is spot welded using the copper wire (Figure 5). It is the type of "resistance welding when the thermoelectric heat is generated, sequentially, at a (usually large) number of isolated points (spots), where the mating surfaces are pressed together by an external force during the whole welding process" [23].

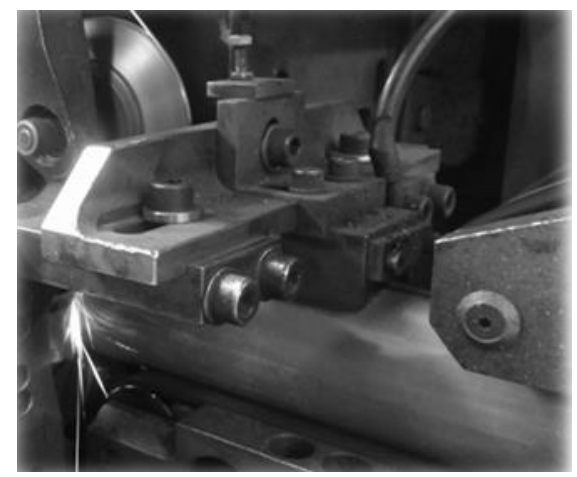

Fig. 5. Welding process (source: Sarten) 
Proper welding is very important for tightness of the can. This is why the number of settings must be fixed: welding current, calibration unit, welding roller parallelism, even overlap (cold welding), insertion (if the two sides of the can body are slipped relative to each other). During production the welding tests are performed and very often special online welding monitor is implemented, and no disjuncture should be observed. The internal and external welds are visible on Figures 6 and 7.

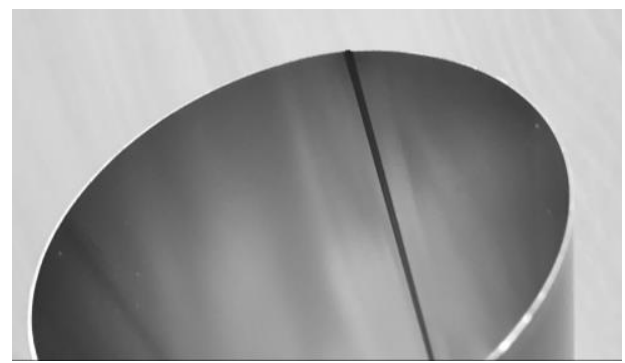

Fig. 6. Internal weld on the aerosol can (own photo)

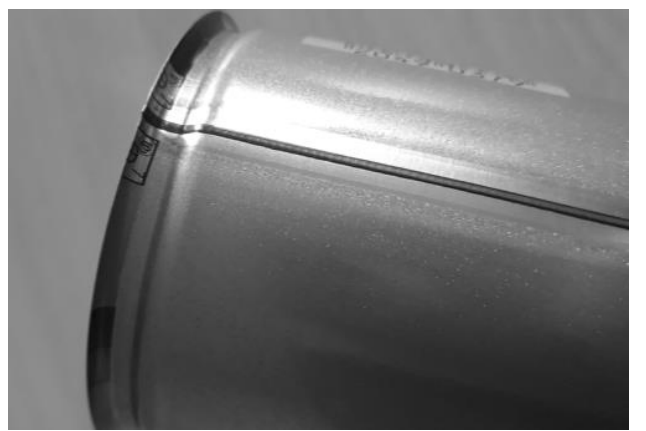

Fig. 7. External weld on the aerosol can (own photo)

\subsubsection{Side stripe lacquering}

As welding and the welding margins are not covered with lacquer nor paint, they contain exposed iron and iron oxide as well as the traces of copper besides the tin. To protect the filling from contamination and the weld from filling impact the side stripe lacquering usually is made [26]. There are two types of side stripe lacquering: liquid and powder. The liquid varnish is applied by spraying on the internal side, and by electrostatic spraying in the case of powder lacquering. For external side stripe lacquer varnishing roller can be used. After applying, cans pass through an oven and cooling in order burn in and become cured and also to solidify of any softened lacquer coating.

Quality of the side stripe lacquering is controlled by immersing the can body into copper sulphate solution and keeping it inside for 2 minutes. If no colour change is observed, the welding line is covered correctly. Another test presented on Figure 8 is made by rubbing over the stripe lacquer with an acetone soaked cotton pad (40 times) and with $\mathrm{CuSO} 4$ solution. If there will be any peeling of the lacquer, the colour will be changed as well.

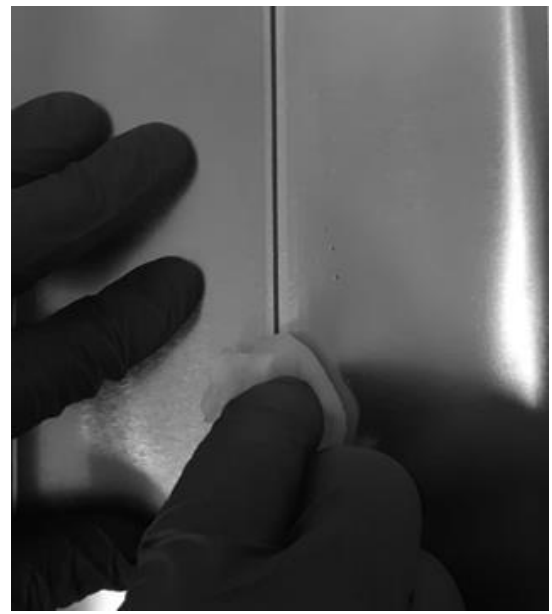

Fig. 8. Side stripe lacquer curing performance test (source: Sarten)

\subsubsection{Neck and flange forming}

The plain cylinder of the can body must be furnished with neck and flange. The flange (Figure 9) and neck (Figure 10) are formed in the multi-step process using forming heads, plates and rollers. Proper neck and flange parameters are required for even and appropriate seaming as those elements are taking important role in the seaming process.

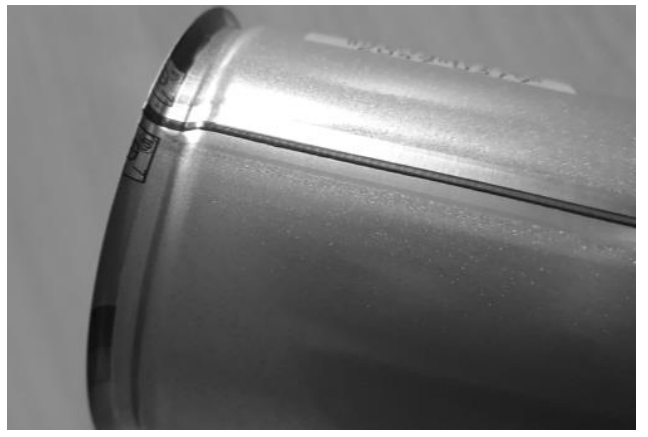

Fig. 9. Flange formed before seaming (own photo)

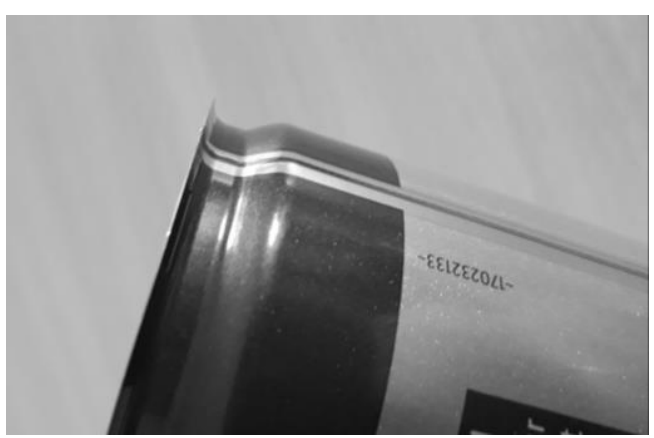

Fig. 10. Neck formed before seaming (own photo)

\subsubsection{Seaming}

Seaming is the next process which after the welding is the key to the aerosol can tightness. The double seam is a metal-to metal connection between can body and endings. It is made of five layers hermetically interlocked two layers from the can body and three from the top or bottom. 
Start
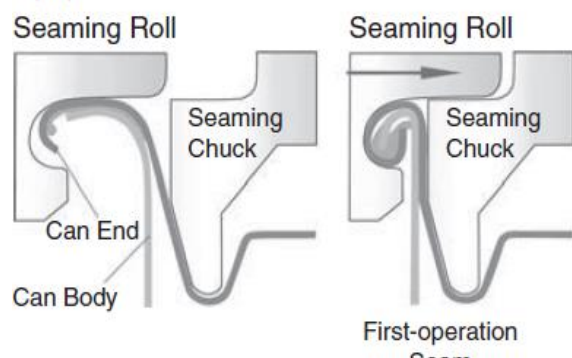

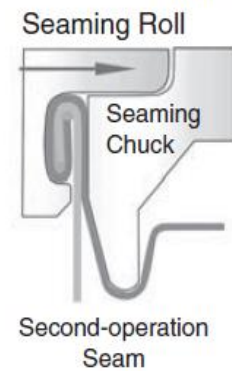

Seam

Fig. 11. A schematic of the double seam process [12]

The operation is made in two steps: the first operation roll makes a semi-seaming, and then the second operation roll finish the seaming, so the elements are connected properly. The seaming chucks are connected with a dial, which moves slower than the chucks. In the case of aerosol cans usually there are six seaming chucks on a dial/roller what means that during a turn of the dial, six cans in a row can be seamed. The schematic process of the double seam is presented on the Figure 11 and the double seam on the top part of the can in presented on the Figure 12.

To ensure a hermetic seal, every angle, radius and dimension must be correct, the sealing compound distribution must be even and does not let the filling to get to the outer side or inversely. Seaming performance test is ensuring that all above is fulfilled. All the important dimensions are controlled under the Seaming Analysis Equipment (Figure 13).

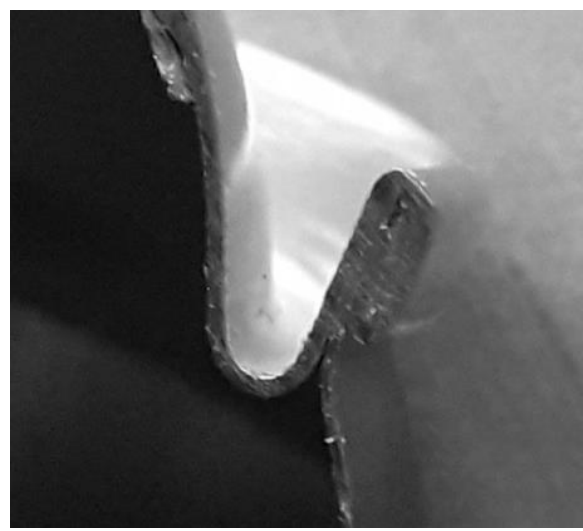

Fig. 12. Double seam (own photo)

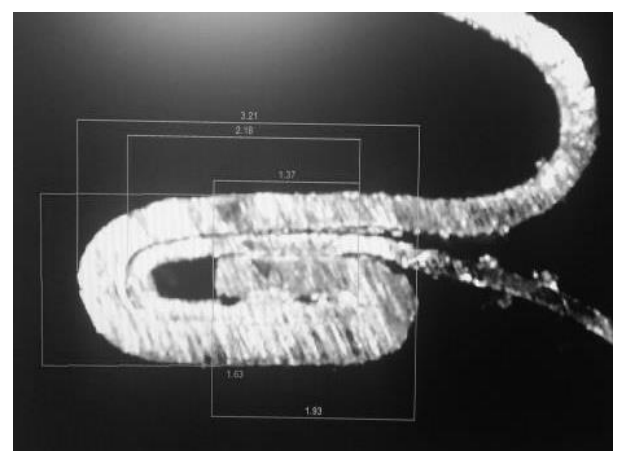

Fig. 13. Double seam under the Seaming Analysis Equipment during the measurement (source: Sarten)

\subsubsection{High pressure testing}

The last step before pelletizing and packing is the high pressure testing. During this online testing, the conveyor carries the aerosol can on a plate which raises the cans and puts them on a tube, the plate closes the tube at the same time. A pneumatic valve carries compressed air inside the aerosol can and does not let the air to come out. On the tube vacuum is created. The working principle of the tester is that when the can leaks, it detects that the pressure in the vacuum increases as the air escapes from the can.

\subsubsection{Tops and bottoms production process}

Tops and bottoms are produced on separated production lines. Sometimes they are also bought from external companies by the can factory manufacturers. The steel used for those elements is always thicker than the one used for the body of the can.

The basic top forming is a six-phase process. Newer machines has nowadays 8-12 phases, which is very important if the thinner materials are used (more phases make the forming more easier without any deformation). Tops' forming phases are presented on the Figure 14. Firstly, from the lacquered and if necessary painted tinplate circles are cut. After that dome forming takes place. A very important element is the curling process, as the tight connection between can and valve depends on that element.

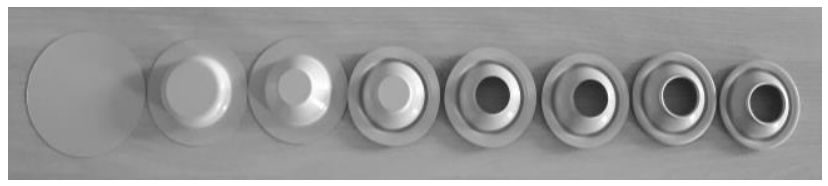

Fig. 14. Tinplate aerosol cans' top forming process (own photo)

Bottoms production process is not so complicated and is made in two steps (Figure 15). From cut circles the bottom is formed.

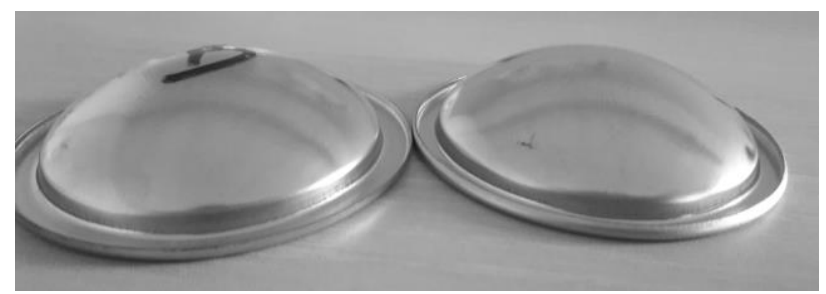

Fig. 15. Tinplate aerosol cans' bottoms forming process (own photo)

The last step of both tops and bottoms production is sealing compound application. This compound helps to make hermetic double seam connection with the body of the can. On the Figures 16 and 17, the differences between tops and bottoms with and 
withous sealing compound are visible.

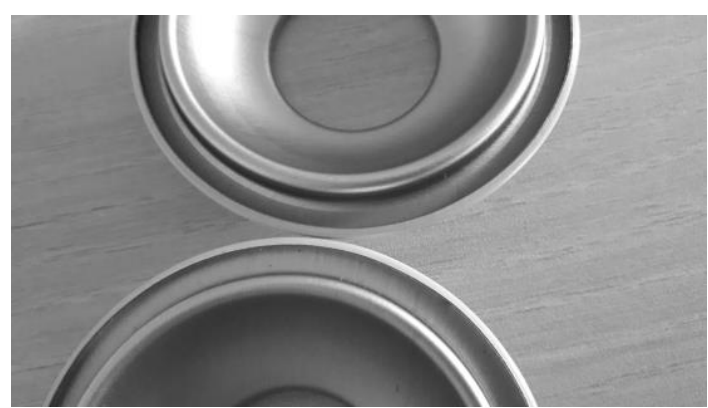

Fig. 16. Top with and without sealing compound (own photo)

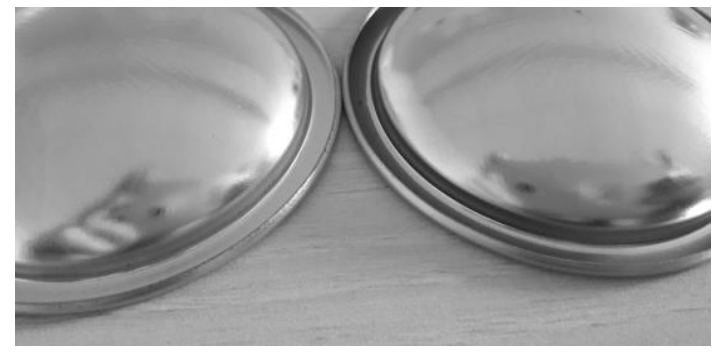

Fig. 17. Bottom with and without sealing compound (own photo)

\section{REQUIREMENTS FOR STEEL AEROSOL CANS}

The production and trading of the aerosol products are subject to many international legal requirements, industry standards and also local laws connected with safety of products, transport, packaging and recycling. All of them must be taken into consideration during production of not only aerosol products' itself but also during manufacturing processes of the aerosol cans. Below we will focus on these requirements which relate to the resistance parameters of the packaging, its dimensions and manufacturing tolerances.

The fundamental European requirements relating to aerosol products are included in the Council Directive of 20 May 1975 on the approximation of the laws of the Member States relating to aerosol dispensers (75/324/EEC) with amendments - called also ADD Aerosol Dispensers Directive [3]. This Directive is specifying among others detailed requirements for ensuring safety as well as conditions and procedures for testing aerosol products with metal containers what has direct impact on the aerosol cans requirements as well.

The detailed requirements regarding aerosol steel containers are regulated by the relevant legal requirements, industry standards, or FEA (European Aerosol Federation) standards and technical specifications [10]. Lists of European norms and FEA standards have been summarized in Tables 1 and 2.
Table 1. Norms for steel aerosols containers [9]

\begin{tabular}{|l|l|}
\hline \multicolumn{1}{|c|}{ No } & \multicolumn{1}{c|}{ Title } \\
EN ISO & $\begin{array}{l}\text { Light gauge metal containers - Definitions and } \\
\text { determination of dimensions and capacities - } \\
\text { Part 3: Aerosol cans (ISO 90-3:2000) }\end{array}$ \\
\hline EN & $\begin{array}{l}\text { Aerosol containers - Tinplate containers - } \\
\text { Dimensions of the 25.4 mm aperture }\end{array}$ \\
\hline EN & $\begin{array}{l}\text { Aerosol containers - Metal containers with 25.4 } \\
\text { mm aperture - Measurement of contact height }\end{array}$ \\
\hline EN & $\begin{array}{l}\text { Metal aerosol containers - Tinplate containers } \\
\text { - Dimensions of two and three-piece cans }\end{array}$ \\
\hline $\begin{array}{l}\text { EN } \\
\text { 15007:2006:2006 }\end{array}$ & $\begin{array}{l}\text { Aerosol containers. Compartmented aerosol } \\
\text { containers }\end{array}$ \\
\hline $\begin{array}{l}\text { ISO } \\
10154: 1991\end{array}$ & $\begin{array}{l}\text { Light gauge metal containers - Three-piece } \\
\text { necked-in tinplate aerosol cans - Dimensions } \\
\text { of the top end }\end{array}$ \\
\hline
\end{tabular}

Table 2. FEA standards for steel aerosol containers [9]

\begin{tabular}{|l|l|}
\hline \multicolumn{1}{|c|}{ No / Issue } & \multicolumn{1}{c|}{ Title } \\
\hline $\begin{array}{l}\text { FEA 216 / } \\
\text { 10/2015 }\end{array}$ & $\begin{array}{l}\text { Metal aerosol containers - Dimensions of } \\
\text { the bearing surfaces of clinching jaws }\end{array}$ \\
\hline $\begin{array}{l}\text { FEA 222 / } \\
\text { 08/2014 }\end{array}$ & $\begin{array}{l}\text { Metal aerosol containers - Guideline for } \\
\text { achieving optimum clinch conditions for } \\
\text { containers with 25.4 mm opening }\end{array}$ \\
\hline $\begin{array}{l}\text { FEA 223 / } \\
\text { 03/2008 }\end{array}$ & $\begin{array}{l}\text { Tinplate aerosol containers - Plastic cover } \\
\text { caps for two and three- piece necked-in } \\
\text { containers conforming with FEA 214 }\end{array}$ \\
\hline FEA 405 / & $\begin{array}{l}\text { Aerosol containers - Definition and method } \\
\text { for measuring parallelism }\end{array}$ \\
\hline $\begin{array}{l}\text { FEA 406 / } \\
\text { 03/2008 }\end{array}$ & $\begin{array}{l}\text { Aerosol containers - Definition and method } \\
\text { for measuring the planeness of the bead }\end{array}$ \\
\hline $\begin{array}{l}\text { FEA 421 / } \\
\text { 03/2008 }\end{array}$ & $\begin{array}{l}\text { Aerosol containers with 25.4 mm opening - } \\
\text { Definition and measurement of cover seat } \\
\text { height }\end{array}$ \\
\hline $\begin{array}{l}\text { FEA 621 / } \\
\text { 03/2007 }\end{array}$ & $\begin{array}{l}\text { Aerosol containers - Measurement of } \\
\text { internal pressure resistance of empty } \\
\text { containers without valves }\end{array}$ \\
\hline $\begin{array}{l}\text { FEA 651 / } \\
\text { 10/2015 }\end{array}$ & $\begin{array}{l}\text { Metal aerosol containers and valves - } \\
\text { Assessment of internal coating coverage }\end{array}$ \\
\hline
\end{tabular}

\section{CHANGES AND INNOVATIONS IN STEEL AEROSOL CONTAINERS' PRODUCTION}

Since the beginning of the aerosol industry history, the most visible changes of the metal aerosol containers are the shape and weight of the aerosol can as well as the thickness of the aerosol containers' walls. The steel aerosol cans' producers are focused on innovations within their processes. Despite all the planned goals within innovations, the aerosol containers must fulfil all the above - mentioned legal requirements and standards.

\subsection{Steel thickness reduction}

The reduction of the steels' thickness is one of the most visible changes in the cans' production. First aerosol cans were $2.3 \mathrm{~mm}$ thin and now the aim is to achieve body gauge at $0.13 \mathrm{~mm}$ [20]. 
Arcelor Mittal had introduced steel which achieves $25 \%$ thickness reduction in the body of the can and in cooperation with Trivium Packaging propose the lightest 3-piece steel aerosol can [20]. Another steel producer - thyssenkrupp Steel Europe-achieved weight reduction of up to $14 \%$ compared to standard aerosol cans $[22,28]$. One of the world known aerosol containers producers - Canpack has reduced the thickness of the body by $11.5 \%$ and due to this fact was able to save the resources of the materials [27].

Sarten Ambalaj - the Turkish tinplate aerosol cans' manufacturer that has expanded its operations globally is continuously running studies to reduce tinplate thickness of aerosol cans. Since 1986 they achieved $30 \%$ reduction in thickness with the conventional aerosol can production technology. What is more, with their new aerosol can they reduced thickness of tinplate by additional $18 \%$ and their cans still comply with law requirements and FEA standards.

Not only the global producers are looking for innovative solutions. Also, Pikopack ZRT., Hungarian producer, since 2019 is running the trials in order to reduce the weight of the cans. They asked and answered many questions during the trials, for example: which parts of the cans should be reduced, which size shows the largest weight reduction, which size is the safest to reduce or which size is the best to sell. Based on those questions we see that the downgauging process must be made in cooperation with not only technical or production, but also marketing and financial departments. Their next goal is to reduce not only the body of the can thickness but also the top of the can. For this they are also planning to reorganize the flange forming process to become more sensitive and to open the gate for thinner materials.

Another interesting innovation is tinplate monoblock aerosol can was introduced at Aerosol \& Dispensing Forum in Paris in 2014 by company Mall Herlan. These cans use less material than standard 3-piece cans and what is also important - have no weld and seams. The production process is very similar to aluminium monoblock cans - Impact Extrusion or Draw and Wall Ironing [30].

\subsection{Shape and decoration innovations}

What can significantly increase the market value of the packaging are additional decorations. In case of tinplate aerosol cans which have high formability and ductility there are many options for unique designs. Manufacturers, by varying the shapes of product packaging, strive to create the uniqueness of their products, and the use of appropriate colors gives the opportunity to create a packaging that will attract the customer's attention. The examples of the ambossing and debossing of steel aerosol cans are presented on
Figures 18 and 19.

The can designers and the canmakers can highlight the logos or some elements by embossing and debossing the parts of the can sometimes even combining with matte or high gloss lacquers [31].

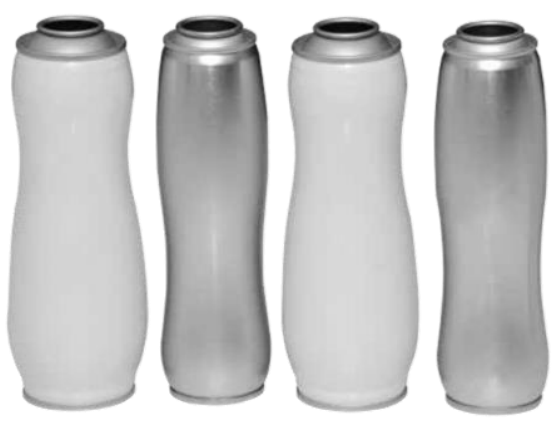

Fig. 18. An example of embossing and debossing of steel aerosol cans from Sarten (source: Sarten)
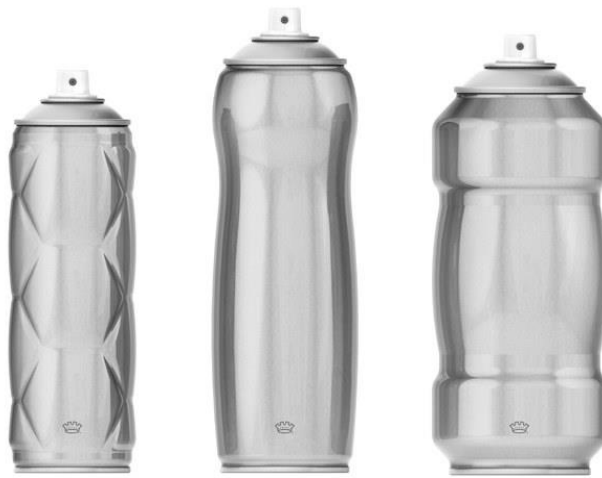

Fig. 19. An example of embossing and debossing of steel aerosol cans from Crown Company [25]

One of the example might be the bulge in the logo area in the Reckitt Benckiser Veet depilating cream [7]. Another example is a Ardagh's complex debossing process for three-piece tinplate aerosol cans used for the ' 212 ' fragrance collection of international fashion designer and brand owner and another one for one of the Europe's leading manufacturers of artistic paint sprays "HARDCORE". The brand owners had encountered problems from counterfeiting in the past, and they were looking for a solution which would guarantee the genuine, refresh the brand and create renewed interest in graffiti art [13, 29].

Also the use of various types of external varnishes: with a "soft touch", pearl, glitter, metallic, fluorescent, "cracked" increase the attractiveness of the products on the shelves. Ardagh's solution provides a perfect presentation for a product, and offers a selection of 45 colours with a high pressure, fast dry gloss finish [1]. Other producers' portfolios also span a wide range of print finishes, because in the competitive market it is challenging to add value in cost-effective way - and varnish is one of the most promising solution [4]. 


\section{CONCLUSIONS}

Tinplate cans are the majority of the aerosol containers. Although the general rules of their production processes does not change significantly, we are observing a real trend on the market today related to innovation in terms of the convenience of using packaging, its eco-friendliness, design, shapes and minimizing the consumption of raw materials. Bearing in mind not only European but also worldwide sustainable approach and circular economy attitude, the ecological path seems to be the best option in order to maintain global growth on the aerosol market without jeopardizing the environment.

\section{ACKNOWLEDGEMENTS}

The author acknowledges the valuable input on the content of this article to companies: PIKOPACK ZRT. from Hungary and SARTEN AMBALAJ SAN. VE TIC. A.Ş. from Turkey.

Paid from the funds of the Ministry of Science and Higher Education under contract No. 12 / DW / 2017/01/1 of 07/11/2017 in the amount of PLN 4433 520.00 .

\section{REFERENCES}

1. Ardagh Group pioneers new debossing techniques for Aerosols (2021). Available form https://www.ardaghgroup.com/news-centre/ardaghgroup-pioneers-new-debossing-techniques-foraerosols, Accesed: 23/05/2021.

2. Bews W. F., (1964). The general principles of pressurized packing, International encyclopedia of pressurised packaging (aerosols), Editors A. Herzka and J. J. Sciarra, pp. 1-15, Pergamon Press Ltd., London.

3. Council Directive of the European Union of 20 May 1975 on the approximation of the laws of the Member States relating to aerosol dispensers, (1975). Official Journal of the European Communities, L147.

4. D'Amato S., (2019). Strong and stable, World aerosols, No. March/April 2019, pp. 34-35.

5. Fitrzyk A., (2011). W sprayu, Packaging Polska, No. 5/2011, pp. 41-41.

6. European Aerosol Federation (2016). Highlights on Aerosol History. Brussel

7. European Aerosol Federation (2020). Annual Report 2019. Brussel.

8. Fitrzyk A., Niemiec K. and Grabowik C., (2018). Trendy $w$ produkcji pojemników aerozolowych, Innowacje $\mathrm{w}$ zarządzaniu i inżynierii produkcji, Editor R. Knosala, pp. 33-43, OW PTZP, Opole.

9. Fitrzyk A., and Niemiec K., (2018). Quality control in aerosol production, Proceedings of $\mathrm{XV}$
International Conference Multidisciplinary Aspects of Production Engineering MAPE vol. 1, pp. 85-91, Panova, Warszawa.

10.Fitrzyk A., (2020). Kryteria oceny jakości opakowań aerozolowych, p. 14, Diffin SA, Warszawa.

11.Gunn-Smith R. A., (1964), Metal containers, International encyclopedia of pressurised packaging (aerosols), Editors A. Herzka and J. J. Sciarra, pp. 2641, Pergamon Press Ltd., London.

12. Heck O. L. and Cabori R., (2009). Can seamers, The Wiley Encyclopedia of packaging technology, Editor K.L. Yam, pp. 181-84, John Wiley \& Sons, Inc., Hoboken.

13. Innovative debossing enhances aerosol cans (2012). Available form https://www.canmaker.com/online/innovative-

debossing-enhances-aerosol-cans/, Accesed: 23/05/2021.

14. Johnsen M. A., (2009). Aerosol containers, The Wiley Encyclopedia of packaging technology, Editor K.L. Yam, pp. 24-31, John Wiley \& Sons, Inc., Hoboken.

15. Johnsen M. A., (2009). Pressure containers, The Wiley Encyclopedia of packaging technology, Editor K.L. Yam, pp. 1015-26, John Wiley \& Sons, Inc., Hoboken.

16. Johnsen M. A., (2016). Evolution of the aerosol can, Spray Technology \& Marketing, No. June 2016, pp. 20-24.

17. Karmazina I., Kukhar V., Balalayeva E., Larkina A. and Kashintseva V., (2019). Experimental methodology for tinplate rolling on a laboratory mill, International Science Conference SPbWOSCE-2018 "Business Technologies for Sustainable Urban Development, Volume 110.

18. Kraus F. J., and Tarulis G. J., (2009). Cans, steel, The Wiley Encyclopedia of packaging technology, Editor K.L. Yam, pp. 205-16, John Wiley \& Sons, Inc., Hoboken.

19. Page B., (2014). Sztywne opakowania metalowe Technika opakowań. Podstawy, materiały, procesy wytwarzania, Editors A. Emblen and H. Emblen, pp. 165-223, PWN, Warszawa.

20. Piqemal C., (2018). The Ultimate DWI Steel can. How beverage may inspire the aerosol market Aerosol and Dispensing Forum 2018, Paris.

21. Rabben M. B., and Arntzen J. G., (2017). Eric Rotheim, Available form https://nbl.snl.no/Erik_Rotheim, $\quad$ Accesed: 07/02/2021.

22. Rasselstein Solidflex makes aerosol cans 14 percent lighter, (2020). Canmaking news, 21 February 2020.

23. Runesson K., Skyttebol A. and Lindgren L. E., (2003). Nonlinear Finite Element Analysis and Applications to Welded Structures, Comprehensive 
Structural Integrity, Editors I. Milne, R. O. Ritchie and B. Karihalo, pp. 255-320, Pergamon.

24. Sarma S. S., Das S. and Mondal K., (2019). The process of manufacturing tinplate, IJRAR June 2019 Volume 6, issue 2.

25. Shaped Aerosol Cans (2016). Available from: https://www.webpackaging.com/en/portals/crown/ass ets/11204628/shaped-aerosol-cans/, Accesed: $31 / 03 / 2021$.

26. Silbereis J. (2009). Metal cans, fabrication, The Wiley Encyclopedia of packaging technology, Editor K.L. Yam, pp. 724-41, John Wiley \& Sons, Inc., Hoboken.

27. Suistanable solutions (2021). Available from: https://www.canpack.com/capabilities/sustainablesolutions/, Accesed: 30/03/2021.

28. Tinplate packaging: the spray can is getting lighter (2020). Available from: https://www.thyssenkruppsteel.com/en/newsroom/highlights/tinplatepackaging-solidflex.html, Accesed: 30/03/2021. 29. Turning collaboration into a fine art (2020). World aerosols, No. March/April 2020, pp. 26-27.

30. Ullmann B., (2014). Suistanable Aerosol Packaging. Tinplate monoblock aerosol cans lead the way, Spray Technology \& Marketing, No. December 2014, pp. 22-25.

31. Van Maercke A., (2018). Containers shape the future, Spray Technology \& Marketing, No. August 2018, pp. 14-16.

Received: March 03, 2021 / Accepted: December 20, 2021 / Paper available online: December 25, 2021 (C) International Journal of Modern Manufacturing Technologies 